\title{
Words on Wheels: Investigating Car Inscriptions in Jordan
}

\author{
Ibrahim Darwish
}

\author{
Rafat Al Rousan
}

Department of Translation, Yarmouk University, Jordan

Doi: 10.36941/jesr-2019-0015

\section{Abstract}

\begin{abstract}
This study investigates the thematic content of car inscriptions in Jordan. A random corpus of 322 car inscriptions was collected from various types of vehicles by the researchers themselves across Irbid Governorate in Jordan in the period 12 January to 30 March, 2019. The corpus was then refined excluding graphics, such as drawings, maps, ready-made stickers, graphs, symbols and other images. Each inscription was individually analysed and thematically tagged. Moreover, inscriptions were tagged for the age of the cars that carried them: old (>10 years old) and new ( $\leq 10$ years old). Lastly, the tags were counted and percentages were extracted. The findings show that car inscriptions in Jordan fall under twelve major themes: religion, philosophy, advertisement, tagging, futility \& fun, patriotism, alliance, brands, romance, instructions, politics and greetings. In addition, the results show that old cars are more likely to be written on than new ones. Finally, it is evident that Jordanian car owners and/or drivers use their moving vehicles as an inexpensive and efficient way for voicing their opinions, beliefs, views, emotions and attitudes in addition to being a low-cost advertising venue.
\end{abstract}

Keyword: graffiti, car inscriptions, thematic analysis, Jordan streets

\section{Introduction}

Although the invention of the car cannot be attributed to any single inventor for it evolved since the dawn of history, it was Benz who drove the first gasoline-driven car in 1886 (Williams, 2010). Naming the new machine was not plain sailing back then either. Some names were proposed but soon discarded, such as motor fly, locomotive car, automation and motorig. In contrast, "[a]utomobile (from the Greek words meaning 'self-moving') and motor car caught on" (Williams, 2010 , p. 21). Whether pushed, pulled or gasoline-driven, cars have always facilitated mobility as a convenient medium of transportation. However, the functions of cars seem to have extended recently. It seems that, to some car owners and drivers nowadays, cars are not only means of transport, but also means of communicating opinions, attitudes, feelings, interests, etc. (Taluah \& Musah, 2015). Moreover, they might help promote or demote people and products as manifested in the inscriptions written on them. When car owners or drivers choose to inscribe something on the bodies of their cars, they undoubtedly have something to carry across to the receivers, i.e., the readers.

Public inscriptions are very common in the Jordanian landscape. They are found in most public spaces, such as fences, walls, trees and even vehicles. Perhaps car inscriptions are the most intriguing as cars move around frequently spreading the inscribed message to a wide audience (see Taluah \& Musah, 2015). What distinguishes car inscriptions from other types of graffiti is the fact that they are inscribed on moving vehicles and hence have higher probability of 
being read and interpreted. While both pedestrians and drivers can read them, drivers have more opportunities to do so, i.e., while driving behind them on the road or when stopping behind them on traffic lights. Cars are indeed interesting inexpensive communication media that can be used to convey different philosophical, political, religious and social messages. The inscriptions may be original or taken from other sources, such as the Holy Quran, proverbs, newspapers, T.V. programmes, etc. Moreover, they may relate to the collective experience of the speech community or to personal experiences only known to the owners or drivers themselves (see van der Geest, 2009). On the receiving end, readers often indulge in deciphering the intended messages of those inscriptions, especially the metaphorical ones. The writers of this study have spent more time interpreting some inscriptions than others and, sometimes, needed to consult others in order to do so as some messages relate to personal or ethnic experiences.

\section{The Aim of the Study}

The aim of this study is to investigate the thematic content of car inscriptions in Jordan via a thematic analysis, an approach "for identifying, analysing and reporting patterns (themes) within data" (Braun \& Clarke, 2006, p. 79). Specifically, it tries to answer the following research questions: 1) "What are the major themes of car inscriptions in Jordan?," 2) "What are the most frequent themes of Jordanian car inscriptions?" and 3) "Is there any relationship between the age of the car and the frequency of inscriptions?."

\section{Graffiti and Car Inscriptions}

Graffiti is a term that is often used loosely to refer to all shapes and forms of street art. However, graffiti proper only refers to the unsanctioned lettering of public spaces. In fact, this is why those involved with graffiti are often referred to as graffiti 'writers' rather than 'artists'. Lewisohn (2008, p. 19) explicates that graffiti writing is about the "tag, it's about graphic form, it's about letters, styles and spray-paint application, and it's about reaching different locations". Graffiti and street art share various aspects, the most important of which is the fact that both are unsanctioned and considered vandalism because the writers/artists do not own the public space they paint. The main function of graffiti is 'tagging', i.e., "to leave a mark somewhere upon the physical environment" (Bates, 2014, p. 23). The most popular tagging shape is a nickname as blu or a nickname with a street number as Taki 183. Other functions of graffiti may hint to some cultural values and overt and covert ways of daily life, such as dating, adverting, joking, etc. (Bates, 2014). Historically, graffiti goes back to prehistoric times when people used to draw and write on rocks (petroglyphs) for various functions, such as marking one's presence through 'tagging' and communicating through carving maps and shapes (see McDonald, 2013).

The etymology of graffiti comes from the $19^{\text {th }}$ century Italian 'graffio' which means 'a scratch' (Oxford Online). The modern-day graffiti appeared in the early $19^{\text {th }}$ century (or late $18^{\text {th }}$ century) to refer to the etchings on the walls of Pompeii in India (Lewisohn, 2008). While prehistoric etching, carving and painting were all sanctioned practices, Pompeian etchings "may be the first documented form of unsanctioned markings" (Bates, 2014, p. 24). Some scholars link modern-day graffiti to 'Foo was here' and 'Kilroy was here' tags that appeared during the first and second World Wars. In the United States, the real emergence of modern-day graffiti occurred in poor neighbourhoods in Philadelphia and New York in the mid-20 $2{ }^{\text {th }}$ century (McDonald, 2013). Back then, gangs utilised graffiti to delineate territorial boundaries in areas of plight and crime. The walls of train and subway stations were then targeted by graffiti writers which sparked confrontations with the authorities who considered the practice a form of vandalism. Graffiti writers stepped up their game by writing on train cars themselves which move from one station to another giving the graffiti taggers more visual exposure. Consequently, the Clean Train Movement was implemented in 1985 in the US to take back the urban visual space from graffiti writers (Gastman \& Neelon, 2010).

Like train car graffiti, car inscriptions cry out for claiming the public space and speaking out on various issues, be they social, political, economic, religious or even futile (Bates, 2014). In other words, car inscriptions could be regarded as one form of graffiti. However, the main difference 
between car inscriptions and graffiti proper centres on the fact that those who write on cars own the vehicles they write on or, at least, have the permission from the owners. Moreover, unlike graffiti, the authorities in most countries do not consider car inscriptions a form of vandalism unless they block the view of the drivers or violate the social, political or religious norms which vary from one country to another. One might also argue that writers on cars want more than 'tag' themselves as the messages on cars cover various themes and serve multiple functions. Several terms are used in the literature to refer to 'car or vehicle graffiti', such as "bumper stickers" (Case, 1992; Bloch, 2000), "vehicle stickers" (Chiluwa, 2008; Dashti, 2017), "truck graffiti" (Basthomi, 2009; Farnia, 2013), "lorry inscriptions" (van der Geest, 2009), "writing on cars" (Al-Qatamin, 2011; Izz al-Din, 2018), "car written manuscripts" (Divsalar \& Nemati, 2012), "graffiti on public service vehicles" (Oganda and Mogambi, 2015), "inscriptions on vehicles" (Taluah \& Musah, 2015) "vehicle graffiti" (El-Nashar \& Nayef, 2016) and "writing on the glass of cars" (Al-Smady, 2016). The term "car inscriptions" will be used throughout this study.

\section{Review of Literature}

In Ghana, Field (1970) attempts to decode car inscriptions to westerners in her ethno-psychiatric study on patient lorry drivers and owners. The data consists of a sample of 144 car inscriptions and a number of interviews with the drivers and owners. The findings show that patient drivers and owners express their fear and anxiety of the unknown future by writing on their vehicles. The themes of the Ghanaian car inscriptions centre on fear of envy and witchcraft that might put the drivers or vehicles at risk. Perhaps this is why, in most of the collected inscriptions, the drivers and owners seek the protection of the supernatural. Field (1970) explains that such inscriptions use both defensive and offensive language. Other functions include unyielding optimism and romance that depict the drivers or owners as heroes. Similarly, Taluah and Musah (2015) claim that car inscriptions in Ghana are the norm rather than the deviation to the extent that owners and drivers deal with them as necessities just like licensing and insuring the vehicles. They have utilised a purposeful sampling technique to collect a large corpus of car inscriptions on commercial vehicles in principal cities and towns in Ghana. The findings conform to Jacobson's (1960) communicative language functions: referential, emotive, phatic, poetic and conative.

In Kenya, Kenyatti (2002) explores gender differences in graffiti written on Kenyan public minibuses. The results show that the minibus graffiti depict women as weak, cheap and (sexually) available. The sexist language used in those graffiti is "popularly treated as a source of humour more often than outrage" (p. 47). Graffitists, according to Kenyatti, need to be educated that undermining others for their gender is never humorous. Likewise, Oganda and Mogambi (2015) who investigate graffiti on Kenyan public service vehicles report that English, Kiswahili, Sheng and the local vernaculars are used in the writings on the public vehicles, but English is the most favoured medium "due to its prestigious status as compared to other languages" (p. 54). The communicative functions or themes of these graffiti vary and include praise, abuse, Biblical references, puns, showing off, etc. Oganda and Mogambi claim that shared background knowledge between graffiti writers and readers is necessary for a successful communication.

In Nigeria, Allo (2006) explores the graffiti and stickers on vehicles that appeared in the 1970s as anti-speeding appeals, such as 'go slow' and 'safe journey'. Later, vehicles graffiti and stickers became markers of social stratification, i.e., old vehicles would carry less socially prestigious statements than the newer ones. Although most of the inscriptions were religious in nature, Allo claims, other themes could be detected, such as political, social and economic. Based on Allo's study, Chiluwa (2008) focuses on the relationship between vehicle stickers and Nigerians' religious identities. He avers that "through stickers people define their individual and group identities within religious institutional practices" (p. 371). In other words, religious tagging on vehicle stickers enables people to voice their religious affiliations in order to gain group acceptance and social security. Moreover, the findings uncover an on-going tension between Islam and Christianity in Nigeria.

Divsalar and Nemati (2012) claim that 'car written manuscripts' are part of the cultural and folkloric tradition of Iranian society. They avouch that by studying inscriptions written on Iranian 
cars, one can detect the often neglected culture of ordinary people (car owners). They focus on the issue of mistrust in what they call car written verses of common poetry. The findings reveal emphasis on themes related to public mistrust, such as disloyalty, hopelessness, envy, ignorance, greediness, selfishness, regret, etc. As for the major themes of Iranian car inscriptions, Farnia and Tohidian (2013) report the following: religion, incarnation, geography, family reference, love, frustration and ethics.

Case (1992) examines 2,160 vehicles in eight parking lots in the city of Riverside in California. He focuses on the messages explicitly displayed on/in the vehicles, such as bumper stickers, suction-cupped items, decals, personalised license plates and/or frames, written or painted messages and any objects displayed or hung on the interior or exterior of the vehicles. Only 844 $(39 \%)$ of the studied vehicles displayed messages. A total number of 1,518 messages were collected from the vehicles under investigation. The findings reveal that those messages fall under six categories: self-identity $(56 \%)$, commercial $(17 \%)$, miscellaneous $(10 \%)$, philosophical $(9 \%)$, ideological $(5 \%)$ and public service $(3 \%)$. The researcher concludes that members of the wealthy families are less inclined to display messages on their vehicles than their unwealthy counterparts. The latter point is further inspected by Basthomi (2009) in Indonesia. On the macro-level, he claims that truck graffiti are the medium of the disadvantaged through which they can deliver their discourse across without the permission of the well-off who control the official media in Indonesia. However, on the mirco-level, he believes that truck graffiti are both egalitarian and authoritative in nature, i.e., truck graffiti "demonstrate the rhetoric of emulation in which the owners exercise their (toothless) power" (p. 217). By the same token, Bloch (2000) discusses the political bumper stickers in Israel which first appeared as a "spontaneous protest medium, evolving into a routinized form of public discourse" (p. 48) all the year round regardless of election seasons. Bloch reveals that bumper stickers represent an untraditional medium of communication that has distinct rules, forms and usages that help ordinary users participate in the national political discourse "bypassing traditional avenues of influence" (p. 48). Some of the merits of bumper stickers as a medium, Bloch explains, are that they require minimal cost, time and effort but, at the same time, offer wide exposure as they are on the move in all cities and towns. Those stickers seem to serve numerous functions in the Israelis society, such as asserting political views, expressing cultural membership, affirming identity, setting issues on the 'public agenda', combatting violence and addressing religion in relation to society.

The phenomenon of writing on vehicles is also widely spread in the Arab World. Izz al-Din (2018) explains that writing on cars was widespread during the seventies in the Arab World, but back then, the writings were confined to proverbs, sayings and anti-speeding statements. Perhaps, the most famous anti-speeding statement was lā tusriৎ yā bāba, fanahnnu bintiợāik 'Don't speed dad, we are waiting for you'. Izz al-Din argues that current car inscriptions are less conservative. To illustrate, a current variant of the famous old anti-speeding statement mentioned above is lā tusriৎ yā bāba, māmā titzawwaj Yalēk 'Don't speed dad, mom might get married after you'. Moreover, the researcher observes that older cars are more likely to be written on than modern ones. As far as the law is concerned, Izz al-Din reports that car inscriptions are illegal in most of the Arab countries on the grounds that they block the driver's view. She concludes that most of car inscriptions in the Arab World nowadays are related to common themes, such as social, economic, romantic, political and comic. In Egypt, El-Nashar and Nayef (2016) explore graffiti on vehicles in different parts of the country. The corpus consists of 614 written vehicle graffiti (pictorial graffiti are excluded). The researchers thematically analysed the patterns of usage of the graffiti in question. The results show the following descending order of the frequency of the themes: religion (54\%), identity $(31 \%)$, social philosophy (14\%) and politics (1\%). Furthermore, the results show that the majority of the graffiti are written in Standard Arabic. The researchers attribute this usage to the high frequency of Quranic and religious citations in the data that are typically written in Standard Arabic, the medium of the Holy Quran. In Kuwait, Dashti (2017) probes the attitudes towards car stickers. The findings unfold negative attitudes towards both the content (religious, political, etc.) and the shape (colour, size, etc.) of car stickers. Reasons behind such negative attitudes include: blocking the driver's view, distracting other drivers, distorting the beauty of the vehicles and reflecting uncivilised behaviour. 
Research on car inscriptions in Jordan is confined to a number of newspaper articles. For example, Al-Qatamin (2011) reports that car inscriptions in Jordan vary in nature and function, such as poetry, drawings, cartoons, songs and sayings. He claims that trucks, vans, pick-ups and taxis are more likely to have inscriptions than other types of vehicles in Jordan. One interesting feature, he claims, is the use of verbal irony to refer to the vehicle itself. For example, you might read șārux el-faḍā? 'space rocket' or habūb ir-RṬh 'wind blow (very fast)' on a slow vehicle and sit al-banāt 'queen bee' or sit al-husin 'the most beautiful' on an old worn-out vehicle. Moreover, Al-Qatamin claims that patriotism is a major theme on cars in Jordan as patriotic statements, drawings and stickers are often found on different types of vehicles. Furthermore, Al-Smady (2016) reports the following common themes of car inscriptions on the streets of Jordan: religion, romance, proverbs, tags, obscenities, advertisements, comedy and warnings. She points out that car inscriptions are widespread in Jordan despite the fact that they infringe the 2008 Jordanian Traffic Law. Article 38, Sections 23-25, prohibits adding anything to the vehicle that might block the rear or side views of the driver. Al-Smady wonders if writing on vehicles constitutes a breathing space for writers or an escape from reality.

\section{Methods and Procedures}

A random corpus of 322 items was gathered by the researchers themselves across Irbid Governorate, the second largest governorate located in the north of Jordan, in the period 12 January-30 March, 2019. The researchers opted for random sampling from various vehicles on the roads of Irbid. Regular car trips were specifically made to collect the data from moving vehicles on the roads of Irbid and nearby highways leading to other administratively affiliated districts, such as al-Qașaba, Bani Obeid, al-Māzār al-Shamāli, Bani Kināna, Kūra, Wistiyya, etc. The corpus was refined excluding graphics, such as drawings, maps, ready-made stickers, graphs, symbols and other images. Graphics combined with text were not excluded but emphasis was specifically placed on the text. Before analysis the corpus included 295 car inscriptions.

As this study is both quantitative and qualitative in nature, each inscription was individually analysed and thematically tagged. Occasionally, the researchers had to inquire among the speech community about the meaning of some unique inscriptions. Whenever both researchers disagreed on a certain inscription theme, a third coder, who is a linguist, was consulted to decide the theme and resolve the ambiguity. The inscriptions were also tagged for the age of the cars that carried them: old (more than 10 years old) and new (less than 10 years old). Lastly, the tags were counted and percentages were extracted using excel.

\section{Findings}

This section expounds the major themes of car inscriptions in Jordan along with their frequency of occurrence. Table 1 shows the number of tokens and the percentages of each theme in our corpus of Jordanian car inscriptions. Each theme will be discussed in detail with transliterated and translated examples (transliterations are italicised while translations are written between single quotations marks). Table 1 reveals that car inscriptions in Jordan fall under twelve general themes: religion, philosophy, advertisement, tagging, futility \& fun, patriotism, alliance, brands, romance, instructions, politics and greetings.

Table 1. Frequency and percentages of themes

\begin{tabular}{|lcc|}
\hline Theme & Tokens/Frequency & Percentage \\
\hline Religion & 105 & $36 \%$ \\
\hline Philosophy & 44 & $15 \%$ \\
\hline Advertisement & 40 & $14 \%$ \\
\hline Tagging & 35 & $12 \%$ \\
\hline Futility \& Fun & 17 & $6 \%$ \\
\hline Patriotism & 16 & $5 \%$
\end{tabular}




\begin{tabular}{|lcc|}
\hline Theme & Tokens/Frequency & Percentage \\
\hline Alliance & 9 & $3 \%$ \\
\hline Brands & 9 & $3 \%$ \\
\hline Romance & 7 & $2 \%$ \\
\hline Instructions & 6 & $2 \%$ \\
\hline Politics & 4 & $1 \%$ \\
\hline Greetings & 3 & $1 \%$ \\
\hline \hline Total & $\mathbf{2 9 5}$ & $\mathbf{1 0 0 \%}$ \\
\hline
\end{tabular}

Moreover, the results show that old cars ( $>10$ years old) are more likely to be written on than new ones ( $\leq 10$ years old). Table 2 illustrates the relationship between the age of the cars and the frequency of inscriptions.

Table 2. Frequency and percentages of inscriptions on old and new cars

\begin{tabular}{|lcc|}
\hline Age of Car & Tokens/Frequency & Percentage \\
\hline Old & 199 & $67 \%$ \\
\hline New & 96 & $33 \%$ \\
\hline \hline Total & $\mathbf{2 9 5}$ & $\mathbf{1 0 0 \%}$ \\
\hline
\end{tabular}

The results in Table 2 are in line with Izz al-Din (2018). As car inscriptions are inexpensive media of communication, it seems that they serve less privileged people more than the rich ones who have access to more mainstream media (see Bloch, 2000). The themes in Table 1 that emerged from the data analysis will be discussed, illustrated and interpreted in relation to Jordanian society:

\subsection{Religion}

In line with previous research (Allo, 2006; Farnia \& Tohidian, 2013; El-Nashar \& Nayef, 2016), Table 1 shows that the most written theme on vehicles in Jordan is religion. This result can lend a helping hand in understanding how faith plays a crucial role in shaping motivation within Jordanian society. Indeed, fearing evil and envy and believing in the power of religion in conquering them is apparently visible in the writings on vehicles in Jordan (see Field, 1970 and van der Geest, 2009 for more information on the relationship between car inscriptions and superstitions). Both defensive and offensive inscriptions against envy can be found in our data, e.g. mā šā? Allah 'May Allah be the protector!' and Yēn al-ḥasūd fiha ৎūd 'May the envious eye be poked!', respectively. Similar to El-Nashar \& Nayef (2016), the following religious sub-themes are found in our data: invocation, preaching and faith reaffirmation, e.g. yā rab 'O Lord', uđkur Allah 'Call thy Lord!', lā ilāha illa Allah 'There is no God but Allah', respectively. Conspicuously, many religious inscriptions contain verses from the Holy Quran although Muslims believe that the words of Allah should always be handled with the deepest respect. It really looks paradoxical when one sees neglected and worn-out writings from the Holy Quran on vehicles.

\subsection{Philosophy}

Considering that car inscriptions are inexpensive communication media, it is not surprising then to find that philosophical and social expressions rank the second in frequency in our data. As members of society, car drivers and owners sometimes feel the need to philosophically express their criticism of the society they live in. To illustrate, some writers express their discontentment of the fading moral values in society, such as honesty, dignity and equality, e.g. māku wafa 'No one has any loyalty anymore!'. Others mix philosophical wisdom with comedy to carry their messages across lightly, e.g. Lāda mazyūne wala marsīdis madyūne 'A pretty second-hand Lada is better than a Mercedes with debt'. Some writers start with the first part of famous proverbs but change the second part sarcastically in order to criticise and condemn certain social events, actions and situations. For example, one of the inscriptions reads man jadda wajad, wa man taxarraja qaSad 
'Who toils, succeeds and who graduates stays unemployed!'. Originally, the famous Arabic proverb reads man jadda wajad, wa man zaraSa hașad 'Who toils, succeeds and who plants, reaps!'. The changed form of the proverb serves as a sarcastic criticism of the government for not tackling unemployment properly. Finally, philosophical threats are also found in our data, e.g. man yahtarim, yuhtaram 'Who respects is respected!'. This inscription serves like a motto for the writer who warns the readers that he/she treats people on the basis of reciprocity.

\subsection{Advertisement}

The third most frequently used theme in our data relates to advertising. Jordanians use their cars as inexpensive venues to advertise various products, such as businesses, election campaigns and the cars themselves. The latter advertisement comes in numerous forms and is written in different languages and symbols, e.g. lilbē $\varsigma$ 'for sale', lilbē $\uparrow+$ phone number 'for sale+phone number', Arbaৎa jayyid+Phone number 'in mint condition+phone number', for sale (in English), or 4 sale (in English), etc. In election seasons, many candidates pay owners and drivers to support them by writing supportive messages on their vehicles. Those are often wiped away when the election season ends. Finally, business owners often write the name of the business, address and phone number on their vehicles.

\subsection{Tagging}

While 'tagging' is the most frequent function and theme of graffiti proper (Lewisohn, 2008), it is the fourth frequent theme in our data, very close to 'advertisement' and 'philosophy' but far less frequent than 'religion' (see Table 1). This clearly demonstrates that car inscriptions and graffiti may share many features but they are not identical. As car inscriptions are not often considered a form of vandalism as graffiti is, it seems that writings on cars have more power in spreading people's values and beliefs. Also, car inscriptions have more exposure than graffiti as they are always on the move. Obviously, the motivation behind tagging is a desire from the writers to leave a mark on the physical place (Bates, 2014). Tagging in our data takes several forms and shapes, such as real names (first and last names), aliases (e.g. alwah̆š 'the monster'), nicknames (abu mahmūd 'the father of Mahmud') and endearing names (e.g. hassūnih 'endearing name for Hassan'). Sometimes these names are followed by phone numbers, and sometimes tagging is done via a mere phone number on the front and back windshield of the car.

\subsection{Futility and Fun}

This theme is an interesting one as most of the inscriptions have a funny side to them. A case in point is the play of words in the proverb about the Lada car mentioned above (see 6.2) where the humorous vibe helps create the major theme. In fact, humour seems to be present in various inscriptions as a micro theme helping the macro themes be more effective. However, some inscriptions are written on cars only for fun, nothing more. For example, one of the inscriptions reads hahahaha. Another reads māzda al-Rūmi where the first part refers to a brand of a car and the second to the family name of a famous female Lebanese singer. The writer blended the funny inscription because the first name of the singer is mājida which is phonetically similar to 'Mazda', the famous Japanese car. The motivation behind creating such inscriptions might be the same as the motivation behind making jokes; that is, making people smile.

\subsection{Patriotism and Alliance}

Inscription writers sometimes try to express their patriotism via certain expressions accompanied with maps, drawings and crowns, e.g. al-mamlaka al-urdiniyyah al-hāšimiyya 'The Hashemite Kingdom of Jordan', abu Hussein 'the father of Hussein, referring to the King' and našāma 'chivalrous, magnanimous and noble, referring to Jordanians'. Jordan is a tribal society, where each person is "identified by family, clan and tribal affiliation, forming a social organization" (Milton- 
Edwards \& Hinchcliffe, 2009, p. 20). Thus, some writers like to express their alliance to their families and tribes by writing the names of their tribes on their cars, e.g. Sbēdāt and bani șaxir. What differentiates this theme from 'tagging' is the fact that these inscriptions are accompanied with other drawings and maps indicating their alliance.

\subsection{Least Frequent Themes}

The least frequent themes in our data include brands (e.g. adidas), romance (e.g. love with initials), instructions (e.g. for your remarks call 079***), politics (e.g. rahima Allahu șaddām 'May Allah have mercy on Saddam') and greetings (e.g. șabāḥu 'Good morning!'). Each of these themes occurs less than ten times in our data. Even though the researchers expected the writers to express their political views frequently in their car inscriptions, they did not. As intriguing as this result may appear, it seems that in the Arab World, politics is still a taboo topic even though the governments are less strict as they used to be in the past. Evidence can be found in other neighbouring Arab countries. El-Nashar and Nayef (2016) report similar results in Egypt which witnessed two political revolutions recently!

\section{Discussion}

It is evident that drivers write more on old cars than new ones. Two third $(67 \%)$ of the inscriptions were found on old cars (>10 years old). The prevalence of inscriptions on old cars may be attributed to several factors. The first important one is that cars represent a convenient and an inexpensive medium of communication through which the disfranchised and less privileged can vent out their views, concerns, complaints, ideas, and interests to a wide audience. This agrees with Bloch (2000) and Izz al-Din (2018). Less privileged people often feel discriminated against in the society and denied access to media of communication; therefore, they turn to car inscriptions in order to protest against neglect, discrimination and injustice. Furthermore, they use their cars as a platform to emphasize their identity and let others know that they exist. Drivers of old cars may also try to draw the attention of others by making themselves visible through the use of inscriptions on their vehicles. Some of them may be looking for fame, recognition, attractiveness, and respect as some of them feel socially alienated and dispossessed. Finally, drivers of old cars try to add a beautifying touch on their vehicles, especially beat-up ones. This practice may give them a sense of selfsatisfaction and confidence.

As far as the language of the inscriptions is concerned, it has been observed that car drivers in Jordan use various linguistic varieties in their car inscriptions: Standard Arabic, Jordanian Arabic, and English. They also use mixed Arabic and English. The use of these forms indicates that individuals in Jordanian society live in a multilingual situation where different forms of language are being used. Noteworthy is the fact that the linguistic situation in Jordan as in most Arab countries is diglossic, where two distinct varieties of the same language are used within the same speech community, a high level and a low level of the same language (Ferguson, 1971). Standard Arabic is the official and formal language used in education, media and government. It is the language of the Holy Quran, the religious sayings and instructions, and poetry. Since religion is the most frequent theme (see Table 1), most of car inscriptions have been written in Standard Arabic. The widespread use of standard Arabic in the inscriptions indicates that it still preserves its status in this community and is still used outside the formal domains. Colloquial (Jordanian) Arabic has also been used in Jordanian car inscriptions. This form of language is often associated with informality, closeness and intimacy. Users of a colloquial form usually attempt to establish and maintain social identity and group cohesiveness within a certain group. Colloquial Jordanian Arabic has mainly been used in the inscriptions related to patriotism, loyalty, advice, wisdom, proverbs, etc. Colloquial language can be used as an expressive form of language that conveys emotions, feelings and attitudes. Writers usually try to win the hearts of their readers by sending their messages using colloquial language. The way car inscriptions are written can give insights to language teachers. We believe that it is about time language teachers realised that language is evolving and that deviations from the prescribed traditional grammar and spelling are not always signs of linguistic deterioration but 
rather a natural process often led by the young generation.

The study of graffiti in general and car inscriptions in particular has various implications for educators and counsellors. Şad \& Kutlu (2009, p. 39) assert that "[w]hen youth cannot find people to listen to them, they may express their strongly felt internal experiences and emotions safely by writing" graffiti. Correspondingly, Dashti (2017) reveals that education is inversely propositional to car inscriptions. In other words, Dashti found that the higher the education levels of the participants were, the more they denounced the phenomenon of car graffiti. As car inscriptions are convenient and low-cost breathing spaces for people to express their ideologies and emotions, educators and counsellors can look into the inscriptions written on the students' cars. Put differently, car inscriptions written by students can be unexplored mines from which school, college and university counsellors can infer numerous social and psychological issues the students might be discreetly suffering from. Moreover, violent or racist inscriptions written by students should not be left unaddressed by counsellors.

The data of this study is based on all makes of vehicles on the roads of Jordan. Therefore, it is expected that the drivers of these cars come from different age spectrums, genders and sectors of society. That is why some car inscriptions are also written in English, which is taught in schools and used widely in higher education in Jordan and by many people across the country. It is a language deemed prestigious by many Jordanians, especially girls. The use of English reveals the writer's desire for upward mobility. Some people try to improve their socio-economic status by using English in their speech and writing (Wardhaugh, 2006). In addition, other drivers employ both Arabic and English in their inscriptions, showing knowledge of both languages. Again, mixing English and Arabic reflects the writers' desire for upward social mobility.

\section{Conclusion}

The primary objective of this study is to explore the thematic content of car inscriptions in Jordan. The thematic analysis of the data collected reveal that car inscriptions in Jordan fall under twelve main themes, including religion, philosophy, advertisement, tagging, futility \& fun, patriotism, alliance, brands, romance, instructions, politics and greetings. Moreover, the results show that inscriptions are more spread on old cars than on new ones. This study may be replicated by other researchers with a larger corpus to explore the same phenomenon but with a wider focus. For instance, examining the communicative functions of car inscriptions in Jordan may yield interesting findings that help better fathom this linguistic phenomenon. Furthermore, a study of gender variation in the use of car inscriptions might reveal more insights about the concerns, interests, attitudes, ways of thinking of men and women in Jordan. A cross-cultural study of car inscriptions is also recommended to help readers understand similarities and differences across cultures with respect to this issue. Finally, this study recommends others to delve into car inscriptions from a purely syntactic perspective to investigate the syntactic structures of these inscriptions.

\section{References}

Allo, T. (2006). A discourse analysis of graffiti and stickers on Lagos vehicles (Unpublished bachelor dissertation). Covenant University, Ota, Nigeria.

Al-Qatamin, F. (2011). Al-Kitāba Yala as-Sayyārāt: Isqāțāt taSkis aš-Šaxsiyya wal qiyam al-MujtamaCiyya [Writing on cars: Projections reflecting personality and social values]. Retrieved from https://alghad.com/ الكتابة_على_النيار ات_إسقاطات_عكس_الث

Al-Smady, M. (2016). Al-Kitāba Sala zujāj as-Sayyārāt: Mutanaffas lilhumūm am hurūbun minal wāqiৎ [Writing on the glass of cars: A breathing space or an escape from reality]. Retrieved from

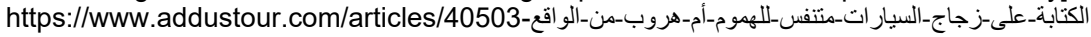

Bates, L. (2014). Bombing, tagging, writing: An analysis of the significance of graffiti and street art (Unpublished master's thesis). University of Pennsylvania, Philadelphia, PA.

Basthomi, Y. (2009). Truck graffiti: The rhetoric of emulation. In E. Weigand (Ed.), Dialogue analysis XI: Proceedings of the 11th IADA conference on 'Dialogue Analysis and Rhetoric' (217-228). IADA Online Series. 
Bloch, L. (2000). Mobile discourse: Political bumper stickers as a communication event in Israel. Journal of Communication, 50(2), 48-76.

Braun, V. \& Clark, V. (2006). Using thematic analysis in psychology. Qualitative Research Psychology, 3, 77101.

Case, C. (1992). Bumper stickers and car signs ideology and identity. The Journal of Popular Culture, 26(3), 107-119.

Chiluwa, I. (2008). Religious vehicle stickers in Nigeria: A discourse of identity, faith and social vision. Discourse \& Communication, 2(4), 371-387.

Dashti, A. (2017). Kuwaitis' attitudes towards vehicles' stickers in Kuwait: A sociolinguistic investigation. International Education Studies, 10(10), 78-89.

Divsalar, F. \& Nemati, A. (2012). Social pathology of trust in car written manuscripts. Mediterranean Journal of Social Sciences, 3(3), 363-372.

El-Nashar, M. \& Nayef, H. (2016). 'Discourse on the go': Thematic analysis of vehicle graffiti on the roads of Egypt. Advances in Language and Literary Studies, 7(5), 227-239.

Farnia, M. \& Tohidian, I. (2013, March 2-3). A thematic analysis of truck graffiti in Iranian context. Paper presented at the First National Conference on Research in Teaching English, Translation and Linguistics (RTELT): Islamic Azad University of Khorasgan, Iran.

Ferguson, C. (1971). A language structure and language use: Essays. Redwood: Stanford University Press.

Field, M. (1970). Search for security: An ethno-psychiatric study of rural Ghana. New York: W. W. Norton \& Company.

Gastman, R. \& Neelon, C. (2010). The History of American Graffiti. New York: Harper Design.

Izz al-Din, N. (2018). Al-Kitāba Sala as-Sayyārāt: Fukāha wa durūs hayātiyya mutanaqqila [Writing on cars:

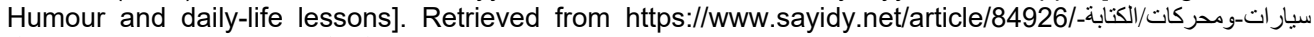
على_السبار ات_فكاهة-ودرو $\square$-حيا ية_متنقلة

Kenyatti, M. (2002). Language as a tool of abuse against women: The case of the language of PSV touts and male university students in Nairobi (Unpublished master's thesis). University of Nairobi, Nairobi.

Lewisohn, C. (2008). Street art: The graffiti revolution. New York: Abram Publishing.

McDonald, F. (2013). The popular history of graffiti: From the ancient world to the present. New York: Skyhorse Publishing.

Milton-Edwards, B. \& Hinchcliffe, P. (2009). Jordan: A Hashemite Legacy. London: Routledge.

Oganda, O. \& Mogambi, H. (2015). The language of graffiti on public transport vehicles in Kenya: Issues and perspectives. International Journal of Education and Research, 3(6), 47-56.

Şad, S.N., \& Kutlu, M. (2009). A Study of graffiti in teacher education. Egitim Arastirmalari-Eurasian Journal of Educational Research, 36, 39-56.

Taluah, A. \& Musah, A. (2015). Moving poetics: A linguistic analysis of inscriptions on vehicles. The Dawn Journal, 4(2), 1126-1139.

van der Geest, S. (2009). 'Anyway!': Lorry inscriptions in Ghana. In J. Gewald, S. Luning \& K. van Walraven (Eds.), Speed of change: Motor vehicles and people in Africa, 1890-2000 (pp. 253-293). Leiden: Brill.

Wardhaugh, R. (2006). An introduction to sociolinguistics. New York: Blackwell Publishing Ltd.

Williams, B. (2010). Breakthroughs in science and technology: Who invented the automobile? Mankato: Arcturus Publishing. 